\title{
Epidemiology of hepatocellular carcinoma
}

Mimi C Yu PhD, Jian-Min Yuan MD PhD, Sugantha Govindarajan MD, Ronald K Ross MD

MC Yu, J-M Yuan, S Govindarajan, RK Ross. Epidemiology of hepatocellular carcinoma. Can J Gastroenterol 2000;14(8): 703-709. Although rare in Canada and the United States, hepatocellular carcinoma (HCC) ranks as the eighth most common cancer in the world. High-risk regions are East and Southeast Asia, and sub-Saharan Africa. Independent of race and geography, rates in men are at least two to three times those in women; this sex ratio is more pronounced in high-risk regions. Rates of HCC in the United States have increased by $70 \%$ over the past two decades. Registry data in Canada and Western Europe show similar trends. In contrast, the incidence of HCC in Singapore and Shanghai, China, both high-risk regions, has declined steadily over the past two decades. Among white and black Americans, there is an inverse relationship between social class status and HCC incidence. Chronic infection by the hepatitis B virus (HBV) is by far the most important risk factor for $\mathrm{HCC}$ in humans. It is estimated that $80 \%$ of HCC worldwide is etiologically associated with HBV. In the United States, although the infection rate in the general population is low, HBV is estimated to account for one in four cases of $\mathrm{HCC}$ among non-Asians. Chronic infection by the hepatitis $\mathrm{C}$ virus is another important risk factor for HCC in the United States; however, this virus is believed to play a relatively minor role in the development of HCC in Africa and Asia. Dietary aflatoxin exposure is an important codeterminant of HCC risk in Africa and parts of Asia. In Canada and the United States, excessive alcohol intake, cigarette smoking and oral contraceptive use in women also are risk factors for HCC.

Key Words: Alcohol; Epidemiology; Hepatocellular carcinoma; Oral contraceptives; Risk factors; Tobacco; Virus

\section{Épidémiologie de l'hépatocarcinome}

RÉSUMÉ : Bien que rare au Canada et aux États-Unis, l'hépatocarcinome se classe au huitième rang parmi les cancers les plus répandus dans le monde. Les régions à haut risque sont l'Asie de l'Est et du Sud-Est et l'Afrique sub-saharienne. Indépendamment de la race et du lieu géographique, les taux sont au moins deux ou trois fois plus élevés chez l'homme que chez la femme. Cette distribution liée au sexe est plus prononcée dans les régions à risque élevé. Aux États-Unis, les taux d'hépatocarcinomes ont augmenté de $70 \%$ au cours des deux dernières décennies. Les données tirées de registres canadiens et de l'Europe de l'Ouest révèlent une tendance similaire. En revanche, l'incidence de l'hépatocarcinome à Singapour et à Shanghai, en Chine, qui font partie des régions à haut risque, a pour sa part constamment diminué au cours des deux dernières décennies. Chez les Américains de race blanche et de race noire, on note un lien inversement proportionnel entre le statut socio-économique et l'incidence de l'hépatocarcinome. L'infection chronique par le virus de l'hépatite B (HBV) est de loin le plus important facteur de risque à l'égard de l'hépatocarcinome chez l'être humain. On estime que 80 \% des hépatocarcinomes dans le monde ont un lien étiologique avec l'HBV. Aux États-Unis, bien que le taux d'infection de la population générale soit faible, l'HBV serait responsable d'un cas sur quatre chez les non-asiatiques. L'infection chronique par le virus de l'hépatite C est un autre important facteur d'hépatocarcinome aux ÉtatsUnis. Par contre, ce virus jouerait un rôle relativement mineur dans le développement de l'hépatocarcinome en Afrique et en Asie. L'exposition à l'aflatoxine alimentaire est un important codéterminant du risque d'hépatocarcinome en Afrique et dans certaines régions d'Asie. Au Canada et aux États-Unis, la consommation excessive d'alcool, le tabagisme, l'emploi de contraceptifs oraux chez les femmes constituent également des facteurs de risque d'hépatocarcinome.

Department of Preventive Medicine, University of Southern California/Norris Comprehensive Cancer Center, Keck School of Medicine, Los Angeles, California 90089-9176, USA

Correspondence and reprints: Mimi C Yu, USC/Norris Comprehensive Cancer Center, 1441 Eastlake Avenue, Los Angeles, California 90089-9176, USA. Telephone 323-865-0842, fax 323-865-0104, e-mail mimiyu@hsc.usc.edu

Received for publication September 3, 1999. Accepted September 13, 1999 
A lthough relatively rare in Canada and the United States, primary liver cancer is a common malignancy worldwide. It ranks as the eighth most common cancer, accounting for $4 \%$ of all newly diagnosed cancers in both sexes (1). The dominant form of primary liver cancer is hepatocellular carcinoma (HCC). Most other primary liver cancers are cholangiocarcinomas, which are histologically and etiologically distinct from HCC. In the United States, HCC constitutes $70 \%$ to $75 \%$ of cases of primary liver cancer (2,3). In most high-risk regions (East and Southeast Asia, and sub-Saharan Africa), well over $90 \%$ of primary liver cancers are HCCs (4). Exceptions are areas with high infection rates of liver flukes (Clonorchis sinensis, Opisthorchis viverrini), which are established etiological agents of cholangiocarcinoma (5). In an area in northeast Thailand where O viverrini infection is endemic, $90 \%$ of primary liver cancers are cholangiocarcinomas (6).

International comparisons of cancer incidence usually do not distinguish between the two distinct types of primary liver cancer. Therefore, most available descriptive data are for primary liver cancer as a whole. However, because cholangiocarcinoma exhibits little variation overall in worldwide incidence (5), any observed racial and geographical variations in primary liver cancer are likely the result of HCC demographic variability.

\section{DEMOGRAPHIC PATTERN}

International variation: The incidence of primary liver cancer varies as much as 100 -fold between high-risk and lowrisk regions in the world - among the highest international variability of all major cancers. The highest rates are found in East and Southeast Asia, and sub-Saharan Africa, while the lowest rates are observed in North America and Western Europe (4). In southern Guangxi, China, a very high-risk area, the age-standardized (world population) incidence is approximately $120 / 100,000$ person-years in men and 30/100,000 person-years in women (7) (Table 1). In contrast, corresponding rates in Danish men and women, lowrisk populations, are $1.6 / 100,000$ person-years and 0.6/100,000 person-years, respectively (4).

North American incidence: Incidence rates of primary liver cancer are fairly uniform across Canada. Overall, the agestandardized rate in men is approximately three/100,000 person-years; the corresponding rate in women is approximately one/100,000 person-years (4) (Table 2).

In the United States, the incidence of primary liver cancer varies five- to eightfold among major racial and ethnic groups (Table 2). The rates in non-Hispanic white men and women are similar to those in Canadian men and women. The incidence in Hispanic and black Americans is roughly two times that in white Americans. Asian Americans exhibit the highest incidence, consistent with the high rates of liver cancer seen in their countries of origin. It is interesting to note that, although Chinese, Japanese and Koreans in Asia have roughly comparable rates of liver cancer, Chinese, Japanese and Korean Americans in Los Angeles, California show a two- to fourfold difference in disease incidence. The
TABLE 1

Average annual age-specific prevalence of primary liver cancer in Fusui County, Guangxi Autonomous Region, China, 1974 to 1977

\begin{tabular}{lcc}
\hline & \multicolumn{2}{c}{ Rate/100,000 } \\
Age (years) & Males & Females \\
\hline $0-9$ & 0.0 & 0.0 \\
$10-19$ & 13.7 & 3.7 \\
$20-29$ & 76.7 & 14.1 \\
$30-39$ & 251.6 & 55.7 \\
$40-49$ & 296.9 & 72.6 \\
$50-59$ & 207.4 & 77.0 \\
$60-69$ & 192.0 & 56.3 \\
$\geq 70$ & 220.9 & 50.5 \\
Age-standardized (world & 119.7 & 31.2 \\
\multicolumn{1}{c}{ population) rate } & & \\
\hline
\end{tabular}

Reproduced with permission from reference 7

TABLE 2

Average annual age-standardized prevalence of primary liver cancer in Canada and the United States, 1988 to 1992

Rate/100,000

\begin{tabular}{lcc} 
Population & Males & Females \\
\hline Canada & 3.1 & 1.2 \\
Los Angeles County, California & & \\
$\quad$ Nonhispanic white & 2.9 & 1.1 \\
Hispanic white & 6.5 & 2.2 \\
Black & 5.1 & 2.2 \\
Chinese & 16.1 & 4.4 \\
Japanese & 5.8 & 3.3 \\
Filipino & 9.5 & 3.5 \\
Korean & 23.9 & 5.5 \\
\hline
\end{tabular}

Reproduced with permission from reference 4

incidence is highest in Koreans, intermediate in Chinese and lowest in Japanese, in parallel to their length of residence in the United States. Most Koreans in Los Angeles are recent immigrants; there were very few Koreans in the United States until the 1970s. On the other hand, migration from Japan to California occurred mostly from the mid1800 s to the early part of this century. Chinese Americans are mainly a mixture of recent immigrants (since the 1970s) and descendants of labourers who came to California during the 'gold rush' (mid- to late 1800s) $(8,9)$. Alaskan natives are also known to have elevated rates of HCC (10).

Sex and age: HCC is a disease with a strong male dominance, which is seen across all populations. Rates in men are at least two to three times higher than the corresponding rates in women. This sex ratio is especially pronounced in high-risk regions (Tables 1, 2).

In low-risk populations, the disease is rare before age 40 years. Thereafter, incidence rates increase as a function of 
approximately the fifth power of age, similar to most other epithelial cancers. In high-risk regions such as southern Guangxi, China, rates begin rising rapidly for both men and women in their 20s. For men, the rates plateau around age 40 to 49 years and decline thereafter. For women, the rates plateau a decade later than for men (ie, around age 50 to 59 years), again with lower rates in older ages (Table 1).

Time trends: In the United States, the incidence of HCC has been increasing steadily over the past two decades such that the overall age-adjusted rate during the period 1991 to 1995 is approximately $70 \%$ higher than that during the period 1976 to 1980. Rates of increase have been comparable between black and white men; these increases are more pronounced than those observed in black and white women (3). Similar time trend data have been reported for other low-risk regions, including Canada, Sweden, Norway and Germany (11). In contrast, the incidence of HCC in Singapore, a high-risk area, has declined by about one-third in both men and women over roughly the same time period (12). The incidence in Shanghai, China, another high-risk region, also has been declining, at the rate of about $1 \% /$ year (13).

A likely explanation for the rising incidence of liver cancer in the United States, Canada and Western Europe is the increased rates of hepatitis $\mathrm{B}$ virus (HBV) and hepatitis $\mathrm{C}$ virus (HCV) infections (both are major risk factors for HCC [see below]) in these population in the 1960s and 1970s. The increased infection rate is thought to have resulted from increased sexual promiscuity and needle sharing with illicit drug use during these decades. Both are risk factors for horizontal transmission of HBV and HCV. The decline in HCC incidence in East Asia may be related to the decreasing exposure to dietary aflatoxin, another major risk factor for HCC (see below) in these high-risk populations. Aflatoxin is a food contaminant arising from poor storage of grains susceptible to mold formation during spoilage. Economic development in East Asia during the past several decades has greatly diminished population exposure to this class of mycotoxins $(14,15)$.

Social class: In Los Angeles, the population-based cancer registry classifies cancer patients according to social class characteristics of their places of residence. Specifically, census information on income and/or educational levels of residents in the neighbourhoods where cancer patients reside is used to rank cancer cases into one of five social class groupings. Figure 1 shows that, in general, lower social class individuals, whether white or black of either sex, have a higher risk of HCC. These results are expected because the prevalence of HBV infection and cigarette smoking, two known risk factors for HCC, are both inversely related to social class among black and white residents of Los Angeles $(16,17)$.

\section{RISK FACTORS}

HBV: HBV is a member of a family of hepatotropic DNA viruses called hepadnaviruses. HBV infection is by far the most important risk factor for HCC in humans. It is estimated that $80 \%$ of HCC worldwide is etiologically associ-

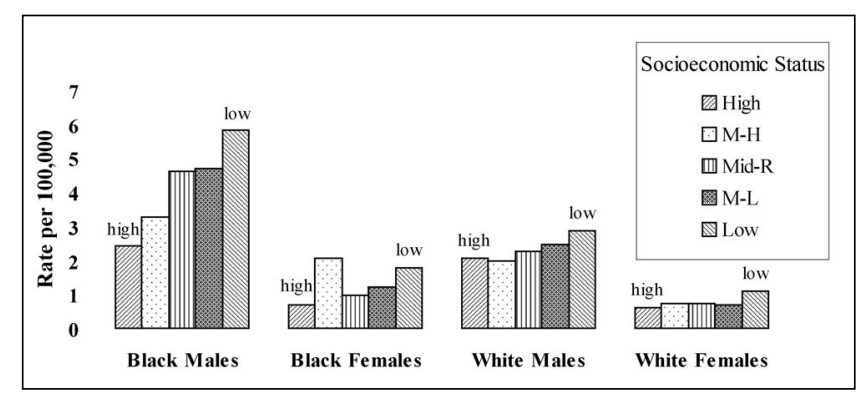

Figure 1) Age-adjusted (1970 United States population) incidence rates (per 100,000 person-years) in black and non-Hispanic white males and females by socioeconomic status groupings, Los Angeles County, California, 1972 to 1995. M-H Middle to high; M-L Middle to low; Mid-R Middle range

ated with chronic HBV infection (18). Among high-risk populations such as the Southern Chinese, it has been shown that the presence of hepatitis $B$ surface antigen ( $\mathrm{HBs} \mathrm{Ag}$ ) in serum (a marker of chronicity) is the single most important predictor of HCC risk. Chinese men who are HBsAg-positive at baseline are 40 to 100 times more likely to develop HCC than are HBsAg-negative men of similar ages $(7,19,20)$. In high-risk areas of China where the population prevalence of $\mathrm{HBsAg}$ positivity in men can be as high as $20 \%$ to $25 \%$, the incidence of HCC among male HBV carriers is about $1 \%$ per year (7). Virtually all carriers acquire the infection from their carrier mothers during infancy (21).

In Canada and the United States, HBV infection is rare in the general population. Subgroups of the population known to experience increased risk of infection are those who come into frequent contact with potentially contaminated blood, such as intravenous drug users, homosexual men, patients on hemodialysis, hemophiliacs, etc (22). Although the rate of exposure is low in the general population, HBV infection is nonetheless responsible for a sizable proportion of HCC cases among non-Asians in the United States. It is estimated that one in four cases of HCC among black and white residents of Los Angeles County can be attributed to HBV (Table 3). In these low-risk populations, however, HBsAg positivity is not the sole serological marker that predicts risk. Individuals who experienced an infection that eventually resolved also have an elevated risk of HCC, although the magnitude of the increase is considerably lower than that in chronic carriers (23) (Table 3).

HCV: HCV is a member of the Flaviviradae family of hepatotropic RNA viruses. Epidemiological studies in diverse populations have established chronic $\mathrm{HCV}$ infection as a major cause of HCC in humans (24). However, there is considerable variation worldwide in its contribution to local HCC burden. In high-risk areas such as China and subSaharan Africa, HCV plays a relatively minor role in HCC development (25-27). On the other hand, in intermediaterisk regions such as Japan and southern Europe, and low-risk regions such as the United States, HCV is responsible for a substantial proportion of total HCC cases (24). In Los Angeles, one-third of HCC cases in black and white residents are 
TABLE 3

Relative risk of hepatocellular carcinoma by hepatitis $B$ virus (HBV) and hepatitis $\mathrm{C}$ virus (HCV) serological status in non-Asians of Los Angeles County, California, 1984 to 1996

\begin{tabular}{|c|c|c|c|}
\hline & $\begin{array}{l}\text { Patients } \\
\text { (with HCC) }\end{array}$ & Controls & $\begin{array}{l}\text { Relative risk } \\
\quad(95 \% \mathrm{Cl})\end{array}$ \\
\hline \multicolumn{4}{|l|}{ HBV markers } \\
\hline HBV negative & 93 & 238 & 1.0 \\
\hline HBV positive* & 57 & 23 & 5.1 (2.9 to 9.1$)$ \\
\hline HBsAg positive & 11 & 0 & $-(6.9 \text { to }-)^{+}$ \\
\hline $\begin{array}{l}\mathrm{HBsAg} \text { negative and } \\
\text { antihepatitis B core } \\
\text { positive }\end{array}$ & 46 & 23 & 3.6 (2.0 to 6.4$)$ \\
\hline \multicolumn{4}{|l|}{ HCV markers } \\
\hline HCV negative & 98 & 255 & 1.0 \\
\hline HCV positive ${ }^{\ddagger}$ & 52 & 6 & $22.3(9.2$ to 53.9$)$ \\
\hline HCV RNA negative ${ }^{\S}$ & 11 & 5 & $4.7(1.5$ to 14.3$)$ \\
\hline HCV RNA positive & 35 & 0 & $-(23.4 \text { to }-)^{+}$ \\
\hline \multicolumn{4}{|l|}{$\mathrm{HBV}$ and HCV markers } \\
\hline $\begin{array}{l}\mathrm{HCV} \text { negative and } \mathrm{HBV} \\
\text { negative }\end{array}$ & 68 & 233 & 1.0 \\
\hline $\begin{array}{l}\text { HCV negative and HBV } \\
\text { positive }\end{array}$ & 30 & 22 & 4.5 (2.4 to 8.6$)$ \\
\hline $\begin{array}{l}\text { HCV positive }{ }^{\ddagger} \text { and } \mathrm{HBV} \\
\text { negative }\end{array}$ & 25 & 5 & 17.5 (6.3 to 48.3$)$ \\
\hline $\begin{array}{l}\text { HCV positive }{ }^{\ddagger} \text { and HBV } \\
\text { positive }\end{array}$ & 27 & 1 & 56.2 (7.3 to 430.8$)$ \\
\hline
\end{tabular}

Population-attributable risks were prior HCV infection alone (21\%), prior $\mathrm{HBV}$ infection alone (13\%) and prior co-infections of HCV and HBV (12\%). *Hepatitis B surface antigen (HBsAg) positive and/or antihepatitis B core positive; ${ }^{+}$There were no controls in this category, thus no finite estimate for the relative risk or its upper $\mathrm{Cl}$ could be calculated; ${ }^{\ddagger}$ Anti-HCV positive; ${ }^{\S}$ Due to insufficient serum, six patients with HCC and one control subject had unknown HCV RNA status. Adapted with permission from reference 34

HCV-related. Among chronic HCV carriers, there is a tremendous difference in HCC risk between those with and those without the presence of HCV RNA in serum (a marker of active viral replication) (Table 3 ).

There is some evidence that $\mathrm{HCV}$ infection is playing an increasingly important role in HCC development among non-Asian Americans. In Los Angeles, the proportion of patients with $\mathrm{HCC}$ who are positive for $\mathrm{HBV}$ and/or $\mathrm{HCV}$ infections remained fairly constant - around $50 \%$ to $55 \%$ during the period 1984 to 1996 . However, there was a noticeable change in the relative contributions of HBV and HCV to viral hepatitis-related HCC cases between the first and second half of this 13-year period. The proportion of $\mathrm{HCV}$-related cases increased from $29 \%$ to $37 \%$, while that of HBV-related cases decreased from $43 \%$ to $35 \%$ (Table 4).

Other hepatitis viruses: The recently discovered hepatitis $\mathrm{G}$ virus (HGV) is an RNA virus belonging to the Flaviviridae family. Chronic viremia may develop after infection. Exposure to blood products is a recognized route of transmission in humans (28-30). In most populations (East Asia, Australia, Western Europe, United States), the prevalence rate of chronic HGV infection in the general population is relatively low, in the range of $1 \%$ to $3 \%$. Exceptions exist, in-
TABLE 4

Proportion of hepatitis B virus (HBV)- and hepatitis C virus (HCV) -related cases of hepatocellular carcinoma among non-Asians of Los Angeles County, California, 1984 to 1996

\begin{tabular}{lcc}
\hline & $\begin{array}{c}\mathbf{1 9 8 4 - 1 9 8 9} \\
\mathbf{n}(\%)\end{array}$ & $\begin{array}{c}\mathbf{1 9 9 0 - 1 9 9 6} \\
\mathbf{n}(\%)\end{array}$ \\
\hline HCV positive* $^{*}$ & $15(29)$ & $37(37)$ \\
HBV positive $^{+}$ & $22(43)$ & $35(35)$ \\
HCV positive* and/or HBV positive $^{+}$ & $27(53)$ & $55(55)$ \\
Total $^{+}$ & $51(100)$ & $99(100)$ \\
\hline
\end{tabular}

*Anti-HCV positive; ${ }^{+}$Hepatitis B antigen positive and/or antihepatitis core positive. Data from references 16 and 34

cluding the populations of São Paulo, Brazil and the black population of South Africa, where rates are estimated at $10 \%$ to $12 \%(31,32)$. Although two case-control studies $(33,34)$ reported a statistically significant association between $\mathrm{HGV}$ and HCC that was unrelated to HBV and HCV, the total body of clinical and epidemiological evidence, including the latest prospective cohort investigation in Shanghai, China, strongly suggests that $\mathrm{HGV}$ is not oncogenic $(29,30,32,35$, 36).

In 1997, a novel DNA virus was identified in a Japanese patient with post-transfusion non- $A$, non-B, non- $C$ hepatitis; the virus was named TT virus after the index case (37). Available evidence indicates that TT virus infection, which has a worldwide distribution, is unlikely to be related to HCC development (38-40).

Dietary aflatoxin: Aflatoxins can induce HCC in a variety of animal species (41). Humans are exposed to these mycotoxins through ingestion of moldy foods, a consequence of poor storage of susceptible grains. Although descriptive studies comparing dietary aflatoxin levels and HCC rates across populations have shown a remarkably linear relationship between exposure level and disease incidence $(7,42,43)$, definitive data linking dietary aflatoxin to HCC in humans became available only recently, after the development of assays to measure aflatoxin metabolites in bodily fluids (urine, blood). Using urinary aflatoxin metabolites as markers of exposure, studies $(44,45)$ have shown that Chinese men with detectable aflatoxin DNA adducts in urine were nine times more likely to develop HCC than those without such urinary adducts. Moreover, a powerful interaction between chronic $\mathrm{HBV}$ infection and aflatoxin exposure in HCC development has been shown; HBV carriers positive for urinary aflatoxin metabolites possessed 60 times the risk of HCC relative to noncarriers negative for urinary aflatoxin metabolites ( $\mathrm{Ta}$ ble 5).

Aflatoxins require metabolic activation to achieve their full carcinogenic potential. Thus, polymorphic genes that participate in aflatoxin metabolism may be part of the reason for the interindividual variability in HCC risk among HBV infected subjects residing in high aflatoxin exposure areas. McGlynn and colleagues (46) examined two such genes, ep- 
oxide hydrolase (EPHX) and glutathione S-transferase M1 (GSTM1), both of which are involved in aflatoxin detoxification in hepatocytes, in a case-control study of HCC in Shanghai, China. GSTM1-null subjects showed an almost twofold risk of HCC compared with non-null subjects, while subjects homozygous for the EPHX mutant allele (which is associated with an approximately $40 \%$ decrease in enzymatic activity) exhibited a fourfold higher risk relative to wild-type homozygotes. Chen et al (47) examined aflatoxin-albumin adduct levels in relation to HCC risk in a cohort of chronic HBV carriers in Taiwan and noted that adduct level was a predictor of risk only in subjects who were GSTM1 and/or GSTT1 null (ie, those relatively deficient in aflatoxin detoxification). The overall evidence, therefore, indicates that the genetically determined ability to metabolize aflatoxin is an important risk factor for HCC in aflatoxin-exposed populations.

Alcohol/tobacco: Clinical studies strongly suggested that excessive alcohol intake was an important contributor to HCC in North America long before epidemiological data confirmed this exposure-disease relationship. A clear excess risk exists, however, only among heavy, long term drinkers (60 drink-years or more); there is no evidence that moderate drinking (one to three drinks a day) is related to increased HCC risk $(17,48,49)$.

Multiple chemical components of cigarette smoke are hepatic carcinogens in animals (50). A number of case-control and cohort studies have investigated cigarette smoking in relation to HCC risk. Evidence seems to suggest that smoking interacts with viral factors in an additive (as opposed to multiplicative) manner in affecting HCC development (17,5153). This may explain the negative findings of studies conducted in HBV endemic regions, which generally lack sufficient sample sizes to examine this association between exposure and disease within the subset of $\mathrm{HBsAg}$-negative subjects. The positive correlation between alcohol and tobacco use in most populations, especially in the West, hampers studies of the association between smoking and HCC. Nonetheless, there is growing epidemiological support for cigarette smoking as an independent risk factor for HCC (54). A recent molecular epidemiological study compared DNA adduct levels of 4-aminobiphenyl, an ingredient of cigarette smoke, in liver tissues of histologically confirmed HCC cases with those of patients with metastatic liver tumours or intrahepatic stones. A statistically significant, dose-response relationship was observed between DNA adduct levels and HCC risk (55).

Estrogen: In the 1970s, a series of case reports followed by case-control studies established oral contraceptives as causal agents of benign liver tumours (hepatocellular adenomas, focal nodular hyperplasias) $(56,57)$. Case reports of hepatocellular carcinoma developing in relatively young women using oral contraceptives also began to surface during that time $(58,59)$. Estrogens, including those in oral contraceptive formulations, are powerful promoters of hepatocarcinogenesis in animals $(60,61)$. The uncontrolled observations linking oral contraceptive use to HCC development were subse-
TABLE 5

Combined effects of hepatitis B surface antigen (HBsAg) positivity and the presence of urinary aflatoxin metabolites on risk of hepatocellular carcinoma in men in Shanghai, China

\begin{tabular}{cccccccc}
\hline & \multicolumn{3}{c}{ Aflatoxin negative } & \multicolumn{3}{c}{ Aflatoxin positive* } \\
HBsAg & Cases & Controls & $\begin{array}{c}\mathbf{R R}^{+} \\
(\mathbf{9 5 \%} \mathbf{~ C l})\end{array}$ & Cases & Controls & $\begin{array}{c}\mathbf{R R}^{+} \\
(\mathbf{9 5 \%} \mathbf{~ C l})\end{array}$ \\
\hline Negative & 5 & 134 & 1.0 & 13 & 102 & $\begin{array}{c}3.4 \\
(1.1-10.0)\end{array}$ \\
& & & & & & 59.4 \\
Positive & 9 & 24 & 7.3 & 23 & 7 & $\begin{array}{c}59.4 \\
(2.2-24.4)\end{array}$ \\
& & & & & $(16.6-212.0)$ \\
\hline
\end{tabular}

*Presence of aflatoxin $B_{1}$, aflatoxin $P_{1}$ or aflatoxin $B_{1}-N^{7}$-Gua; ${ }^{+}$Adjusted for cigarette smoking. RR Relative risk Reproduced with permission from reference 44

quently confirmed by a number of case-control studies conducted in Western populations. These studies consistently demonstrated a strong association between exposure, especially long term use, and risk (17,62-68). However, two studies conducted among women in areas where HBV infection is endemic failed to show any increase in HCC risk among users of oral contraceptives $(69,70)$. Yu et al (17) pointed out that these seemingly disparate observations could be explained by an additive (rather than multiplicative) model of viral (HBV)-hormonal (estrogen) interaction in HCC development. Under the assumption of additive risks, a sample size many times larger than those used in the two latter studies would be required to detect the additional risk in oral contraceptive users against the very high background risk in HBV carriers.

Data are sparse on the possible risk of HCC in users of menopausal estrogen replacement therapy. Yu et al (17) noted a statistically nonsignificant $50 \%$ increase in risk among users of conjugated equine estrogen, but the excess risk disappeared after adjustment for use of oral contraceptives.

Androgens: A series of case reports documented the occurrence of HCC in relatively young men who had been long term users of androgenic steroids (71-73). These clinical observations are consistent with experimental findings showing male animals to be more susceptible to chemically induced HCC than their female counterparts. This sex difference disappears in castrated male animals, but is restored when testosterone is administered to castrated immature male or immature female animals $(41,74)$.

HBV-infected men appear to be more likely than HBVinfected women to progress to the chronic carrier state $(75,76)$. Therefore, testosterone may indirectly contribute to the development of HCC by promoting progression to chronicity after primary HBV infection.

Iron: Primary hemochromatosis is an autosomal recessive disease that is characterized by excessive iron absorption in the gut and storage in multiple organs including the liver. These patients are at extremely high risk for HCC (over 200fold compared with the general population) (77). By screen- 
ing populations in the United States with the use of serum iron measures, a prevalence of one in 200 to one in 400 persons, and a carrier rate of $10 \%$ have been suggested for this disorder (78). One clinical complication of primary hemochromatosis is diabetes mellitus, which may partly explain the observed high risk of HCC among patients with diabetes mellitus $(17,79,80)$.

Black residents of South Africa are potentially exposed to high levels of dietary iron through the intake of home-

\section{REFERENCES}

1. Parkin DM, Laara E, Muir CS. Estimates of the worldwide frequency of sixteen major cancers in 1980. Int J Cancer 1988;41:184-97.

2. Miller BA, Kolonel LN, Bernstein L, et al, eds. Racial/Ethnic Patterns of Cancer in the United States 1988-1992. NIH Publication Number 96-4104. Bethesda: National Cancer Institute, 1996:68.

3. El-Serag HB, Mason AC. Rising incidence of hepatocellular carcinoma in the United States. N Engl J Med 1999;340:745-50.

4. Parkin DM, Whelan SL, Ferlay J, Raymond L, Young J, eds. Cancer Incidence in Five Continents, vol VII. IARC Scientific Publications No. 143. Lyon: International Agency for Research on Cancer, 1997.

5. Parkin DM, Ohshima H, Srivatanakul P, Vatanasapt V. Cholangiocarcinoma: epidemiology, mechanisms of carcinogenesis and prevention. Cancer Epidemiol Biomarkers Prev 1993;2:537-44.

6. Vatanasapt V, Martin N, Sriplung H, et al. Cancer incidence in Thailand, 1988-1991. Cancer Epidemiol Biomarkers Prev 1995:4:475-83.

7. Yeh F-S, Yu MC, Mo C-C, Luo S, Tong MJ, Henderson BE. Hepatitis $B$ virus, aflatoxins, and hepatocellular carcinoma in southern Guangxi, China. Cancer Res 1989;49:2506-9.

8. Ichihashi Y. Japanese in the United States: a critical study of the problems of the Japanese immigrants and their children. California: Stanford University Press, 1932.

9. Mangiafico L. Contemporary American immigrants: patterns of Filipino, Korean, and Chinese settlements in the United States. New York: Praeger, 1988.

10. Heyward WL, Lanier AP, Bender TR, et al. Primary hepatocellular carcinoma in Alaskan Natives, 1969-1979. Int J Cancer 1981;28:47-50.

11. Saracci R, Repetto F. Time trends of primary liver cancer: indication of increased incidence in selected cancer registry populations. J Natl Cancer Inst 1980;65:241-7.

12. Chia KS, Lee HP, Seow A, Shanmugaratnam K. Singapore Cancer Registry Report No. 4. Trends in Cancer Incidence in Singapore 1968-1992. Singapore Cancer Report 1996;4:86-89.

13. Jin F, Devesa SS, Zheng W, Blot WJ, Fraumeni JF, Gao Y-T. Cancer incidence trends in urban Shanghai, 1972-1989. Int J Cancer 1993;53:764-70.

14. Tu J-T, Gao R-N, Zhang D-H, Gu B-C. Hepatitis B virus and primary liver cancer on Chongming Island, People's Republic of China. Natl Cancer Inst Monogr 1985;69:213-5.

15. Guan R, Oon CJ, Wild C, Montesano R. A preliminary survey on aflatoxin exposure in Singapore. Ann Acad Med Singapore 1986;15:201-5.

16. Yu MC, Tong MJ, Coursaget P, Ross RK, Govindarajan S, Henderson BE. Prevalence of hepatitis B and C viral markers in black and white patients with hepatocellular carcinoma in the United States. J Natl Cancer Inst 1990;82:1038-41.

17. Yu MC, Tong MJ, Govindarajan S, Henderson BE. Nonviral risk factors for hepatocellular carcinoma in a low-risk population, the nonAsians of Los Angeles County, California. J Natl Cancer Inst 1991;83:1820-6.

18. Prevention of Liver Cancer. WHO Technical Series, vol 691. Geneva: World Health Organization, 1983.

19. Beasley RP, Hwang L-Y, Lin C-C, Chien C-S. Hepatocellular carcinoma and hepatitis B virus: a prospective study of 22,707 men in Taiwan. Lancet 1981;ii:1129-33.

20. Beasley RP, Hwang L-Y. Overview on the epidemiology of hepatocellular carcinoma. In: Hollinger FB, Lemon SM, Margolis HS, eds. Viral Hepatitis and Liver Disease. Baltimore: Williams \& Wilkins, 1991:532-5. brewed beer that is prepared in nongalvanized iron drums and has been shown to have a high iron content (81). Mandishona et al (82) measured serum ferritin and transferrin saturation in 24 black South African HCC patients and 48 race-, sex- and age-matched control subjects. Five (21\%) patients with HCC versus three $(6 \%)$ control subjects exhibited iron overload (defined as concurrent elevation of serum ferritin and transferrin saturation), a difference that was statistically significant.

21. Wong VCW, Lee AKY, Ip HMH. Transmission of hepatitis B antigens from symptom free carrier mothers to the fetus and the infant. Br J Obstet Gynecol 1980;87:958-65.

22. Alter MJ, Hadler SC, Margolis HS, et al. The changing epidemiology of hepatitis B in the United States: need for alternative vaccination strategies. JAMA 1990;263:1218-22.

23. Yu MC, Yuan J-M, Ross RK, Govindarajan S. Presence of antibodies to the hepatitis B surface antigen is associated with an excess risk for hepatocellular carcinoma among non-Asians in Los Angeles County, California. Hepatology 1997;25:226-8.

24. IARC Monographs on the Evaluation of Carcinogenic Risks to Humans, vol 59. Hepatitis Viruses. Lyon: International Agency for Research on Cancer, 1994.

25. Yuan J-M, Ross RK, Stanczyk FZ, et al. A cohort study of serum testosterone and hepatocellular carcinoma in Shanghai, China. Int J Cancer 1995;63:491-3.

26. Yuan J-M, Govindarajan S, Henderson BE, Yu MC. Low prevalence of hepatitis $\mathrm{C}$ infection in hepatocellular carcinoma (HCC) cases and population controls in Guangxi, a hyperendemic region for HCC in the People's Republic of China. Br J Cancer 1996;74:491-3.

27. Kew MC, Yu MC, Kedde M-A, Coppin A, Sarkin A, Hodkinson J. The relative roles of hepatitis $B$ and $C$ viruses in hepatocellular carcinoma in South African Blacks. Gastroenterology 1997;112:184-7.

28. Linnen J, Wages J, Zhang-Keck Z-Y, et al. Molecular cloning and disease association of hepatitis $G$ virus: a transfusion-transmissible agent. Science 1996;271:505-8.

29. Masuko K, Mitsui T, Iwano K, et al. Infection with hepatitis GB virus $\mathrm{C}$ in patients on maintenance hemodialysis. $\mathrm{N}$ Engl J Med 1996;334:1485-90.

30. Alter HJ, Nakatsuji Y, Melpolder J, et al. The incidence of transfusion-associated hepatitis $\mathrm{G}$ virus infection and its relation to liver disease. N Engl J Med 1997;336:747-54.

31. Bassit L, Saez-Alquezar A, Stuyer L, et al. High prevalence of hepatitis $G$ virus among blood donors in Sao Paulo, Brazil. Hepatology 1996;24:481A. (Abst)

32. Lightfoot K, Skelton M, Kew MC, et al. Does hepatitis GB virus-C infection cause hepatocellular carcinoma in black Africans? Hepatology 1997;26:740-2.

33. Tagger A, Donato F, Ribero ML, et al. A case-control study on GB virus $C /$ hepatitis $G$ virus infection and hepatocellular carcinoma. Hepatology 1997;26:1653-7.

34. Yuan J-M, Govindarajan S, Ross RK, Yu MC. Chronic infection with hepatitis $G$ virus in relation to hepatocellular carcinoma among nonAsians in Los Angeles County, California. Cancer 1999;86:936-43.

35. Kubo S, Nishiguchi S, Kuroki T, et al. Poor association of GBV-C viremia with hepatocellular carcinoma. J Hepatol 1997;27:91-5.

36. Yuan J-M, Govindarajan S, Gao Y-T, Ross RK, Yu MC. Prospective evaluation of infection with hepatitis $G$ virus in relation to hepatocellular carcinoma in Shanghai, China. J Infect Dis. (In press)

37. Nishizawa T, Okamoto H, Konishi K, Yoshizawa H, Miyakawa Y, Mayumi M. A novel DNA virus (TTV) associated with elevated transaminase levels in posttransfusion hepatitis of unknown etiology. Biochem Biophys Res Commun 1997;241:92-7.

38. Yamamoto T, Kajino K, Ogawa M, et al. Hepatocellular carcinomas infected with the novel TT DNA virus lack viral integration. Biochem Biophys Res Commun 1998;251:339-43.

39. Tangkijvanich P, Hirsch P, Theamboonlers A, Nuchprayoon I, Poovorawan Y. Association of hepatitis viruses with hepatocellular carcinoma in Thailand. J Gastroenterol 1999;34:227-33.

40. Pineau P, Meddeb M, Raselli R, et al. Impact of TTV infection on 
hepatocellular carcinoma development: an Euro-Asian Survey. J Infect Dis 2000;181:1138-42.

41. Wogan GN. Aflatoxins as risk factors for hepatocellular carcinoma in humans. Cancer Res 1992;52(7 Suppl):2114S-8S.

42. Peers FG, Linsell CA. Dietary aflatoxins and liver cancer - a population based study in Kenya. Br J Cancer 1973;27:473-84.

43. Van Rensburg SJ, Cook-Mozaffari P, Van Schalkwyk DJ, Van Der Watt JJ, Vincent TJ, Purchase IF. Hepatocellular carcinoma and dietary aflatoxin in Mozambique and Transkei. Br J Cancer 1985;51:713-26.

44. Ross RK, Yuan J-M, Yu MC, et al. Urinary aflatoxin biomarkers and risk of hepatocellular carcinoma. Lancet 1992;339:943-6.

45. Qian G-S, Ross RK, Yu MC, et al. A follow-up study of urinary markers of aflatoxin exposure and liver cancer risk in Shanghai, People's Republic of China. Cancer Epidemiol Biomarkers Prev 1994;3:3-10.

46. McGlynn KA, Rosvold EA, Lustbader ED, et al. Susceptibility to hepatocellular carcinoma is associated with genetic variation in the enzymatic detoxification of aflatoxin B1. Proc Natl Acad Sci USA 1995;92:2384-7.

47. Chen C-J, Yu M-W, Liaw Y-F, et al. Chronic hepatitis B carriers with null genotypes of glutathione S-transferase M1 and T1 polymorphisms who are exposed to aflatoxin are at increased risk of hepatocellular carcinoma. Am J Hum Genet 1996;59:128-34.

48. Yu MC, Mack T, Hanisch R, Peters RL, Henderson BE, Pike MC. Hepatitis, alcohol consumption, cigarette smoking, and hepatocellular carcinoma in Los Angeles. Cancer Res 1983;43:6077-9.

49. Tanaka K, Hirohata T, Takeshita S, et al. Hepatitis B virus, cigarette smoking and alcohol consumption in the development of hepatocellular carcinoma: a case-control study in Fukuoka, Japan. Int J Cancer 1992;51:509-14.

50. Hoffmann D, Rivenson A, Amin S, Hecht SS. Dose-response study of the carcinogenicity of tobacco-specific $\mathrm{N}$-nitrosamines in F344 rats. J Cancer Res Clin Oncol 1984;108:81-6.

51. Trichopoulos D, MacMahon B, Sparros L, Merikas G. Smoking and hepatitis B-negative primary hepatocellular carcinoma. J Natl Cancer Inst 1980;65:111-4.

52. Lam KC, Yu MC, Leung JWC, Henderson BE. Hepatitis B virus and cigarette smoking: risk factors for hepatocellular carcinoma in Hong Kong. Cancer Res 1982;42:5246-8.

53. Trichopoulos D, Day NE, Kaklamani E, et al. Hepatitis B virus, tobacco smoking and ethanol consumption in the etiology of hepatocellular carcinoma. Int J Cancer 1987;39:45-9.

54. Doll R. Cancers weakly related to smoking. Br Med Bull 1996;52:35-49.

55. Wang L-Y, Chen C-J, Zhang Y-J, et al. 4-aminobiphenyl DNA damage in liver tissue of hepatocellular carcinoma patients and controls. Am J Epidemiol 1998;147:315-23.

56. Edmondson HA, Henderson B, Benton B. Liver-cell adenomas associated with use of oral contraceptives. N Engl J Med 1976;294:470-2.

57. Rooks JB, Ory HW, Ishak KG, et al. Epidemiology of hepatocellular adenoma: the role of oral contraceptive use. JAMA 1979;242:644-8.

58. Davis M, Portmann B, Searle M, Wright R, Williams R. Histological evidence of carcinoma in a hepatic tumour associated with oral contraceptives. BMJ 1975;4:496-8.

59. Pryor AC, Cohen RJ, Goldman RL. Hepatocellular carcinoma in a woman on long-term oral contraceptives. Cancer 1977;40:884-8.

60. Yager JD, Yager R. Oral contraceptive steroids as promoters of hepatocarcinogenesis in female Sprague-Dawley rats. Cancer Res $1980 ; 40: 3680-5$.
61. Li JJ, Li SA. High incidence of hepatocellular carcinomas after synthetic estrogen administration in Syrian Golden hamsters fed alpha-naphthoflavone: a new tumor model. J Natl Cancer Inst 1984;73:543-7.

62. Henderson BE, Preston-Martin S, Edmondson HA, Peters RL, Pike MC. Hepatocellular carcinoma and oral contraceptives. Br J Cancer 1983;48:437-40.

63. Neuberger J, Forman D, Doll R, Williams R. Oral contraceptives and hepatocellular carcinoma. BMJ 1986;292:1355-7.

64. Forman D, Vincent TJ, Doll R. Cancer of the liver and the use of oral contraceptives. BMJ 1986;292:1357-61.

65. Palmer JR, Rosenberg L, Kaufman DW, Warshauer ME, Stolley P, Shapiro S. Oral contraceptive use and liver cancer. Am J Epidemiol 1989;130:878-82.

66. La Vecchia C, Negri E, Parazzini F. Oral contraceptives and primary liver cancer. Br J Cancer 1989;59:460-1.

67. Mayans MV, Calvet X, Bruix J, et al. Risk factors for hepatocellular carcinoma in Catalonia, Spain. Int J Cancer 1990;46:378-81.

68 Hsing AW, Hoover RN, McLaughlin JK, et al. Oral contraceptives and primary liver cancer among young women. Cancer Causes Control 1992;3:43-8.

69. The WHO Collaborative Study of Neoplasia and Steroid Contraceptives. Combined oral contraceptives and liver cancer. Int J Cancer 1989;43:254-9.

70. Kew MC, Song E, Mohammed A, Hodkinson J. Contraceptive steroids as a risk factor for hepatocellular carcinoma: a case/control study in South African black women. Hepatology 1990;11:298-302.

71. Johnson FL, Feagler JR, Lerner KG, et al. Association of androgenicanabolic steroid therapy with development of hepatocellular carcinoma. Lancet 1972;ii:1273-6.

72. Farrell GC, Joshua DE, Uren RF, Baird PJ, Perkins KW, Kronenberg H. Androgen-induced hepatoma. Lancet 1975;ii:430-2.

73. Boyd PR, Mark GJ. Multiple hepatic adenomas and a hepatocellular carcinoma in a man on oral methyl testosterone for eleven years. Cancer 1977;40:1765-70.

74. Gurtoo HL, Motycka L. Effect of sex difference on the in vitro and in vivo metabolism of aflatoxin B1 by the rat. Cancer Res 1976;36:4663-71.

75. Lingao AL, Domingo EO, West S, et al. Seroepidemiology of hepatitis B virus in the Philippines. Am J Epidemiol 1986;123:473-80.

76. Sung JL. Hepatitis B virus infection and its sequelae in Taiwan. Proc Natl Sci Council (B) 1981;5:385-99.

77. Niederau C, Fischer R, Sonnenberg A, Stremmel W, Trampisch HJ, Strohmeyer G. Survival and causes of death in cirrhotic and in noncirrhotic patients with primary hemochromatosis. N Engl J Med 1985;313:1256-62.

78. Burke W, Thomson E, Khoury MJ, et al. Hereditary hemochromatosis: gene discovery and its implications for population-based screening. JAMA 1998;280:172-8.

79. Adami H-O, Chow W-H, Nyren O, et al. Excess risk of primary liver cancer in patients with diabetes mellitus. J Natl Cancer Inst $1996 ; 88: 1472-7$

80. Wideroff L, Gridley G, Mellemkjaer L, et al. Cancer incidence in a population-based cohort of patients hospitalized with diabetes mellitus in Denmark. J Natl Cancer Inst 1997;89:1360-5.

81. Bothwell TH, Seftel H, Jacobs P, Torrance JD. Iron overload in Bantu subjects. Studies on the bioavailability of iron in Bantu beer. Am J Clin Nutr 1964;14:47-51.

82. Mandishona E, MacPhail AP, Gordeuk VR, et al. Dietary iron overload as a risk factor for hepatocellular carcinoma in Black Africans. Hepatology 1998;27:1563-6. 


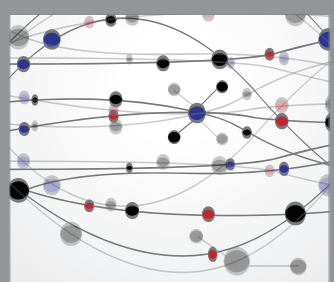

The Scientific World Journal
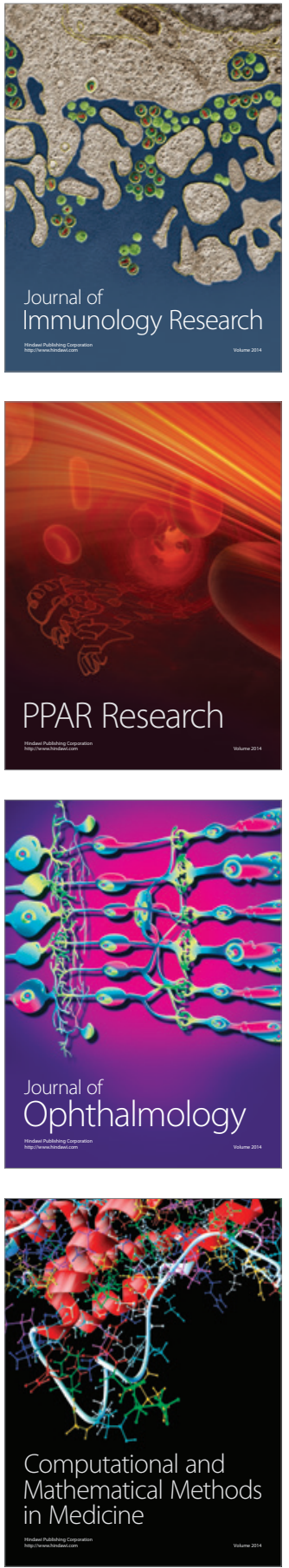

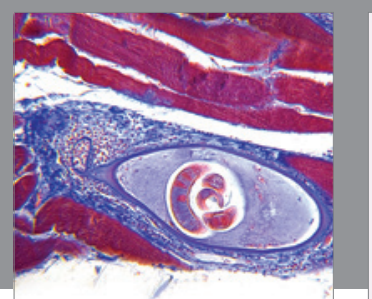

Gastroenterology Research and Practice

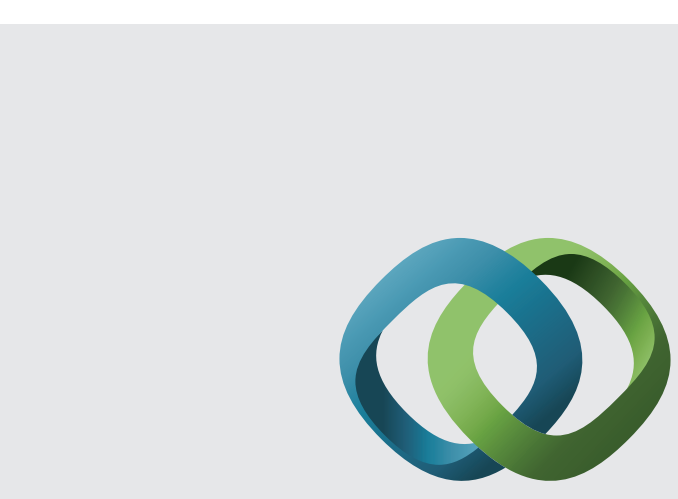

\section{Hindawi}

Submit your manuscripts at

http://www.hindawi.com
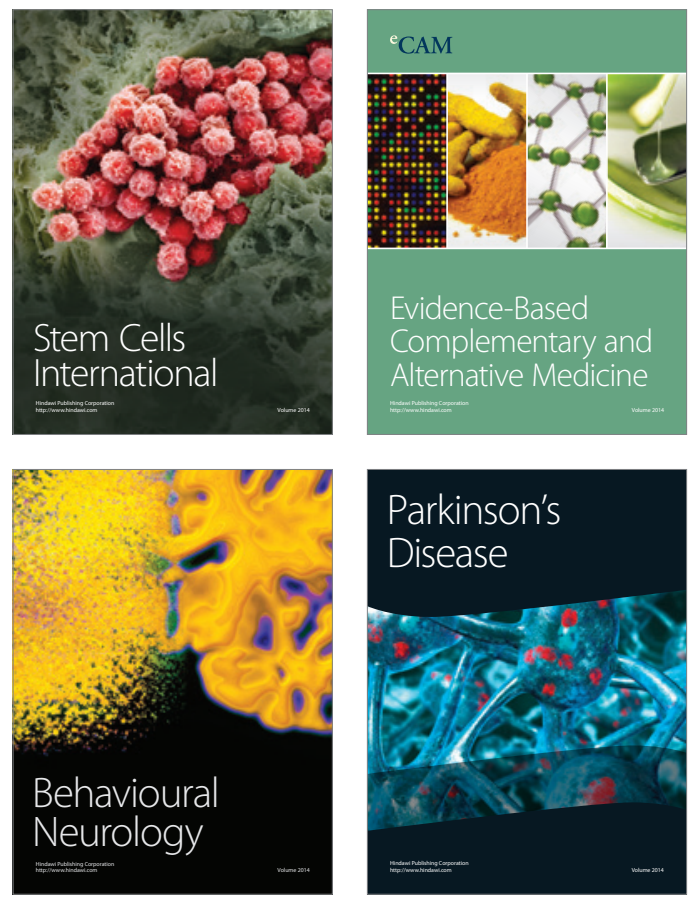
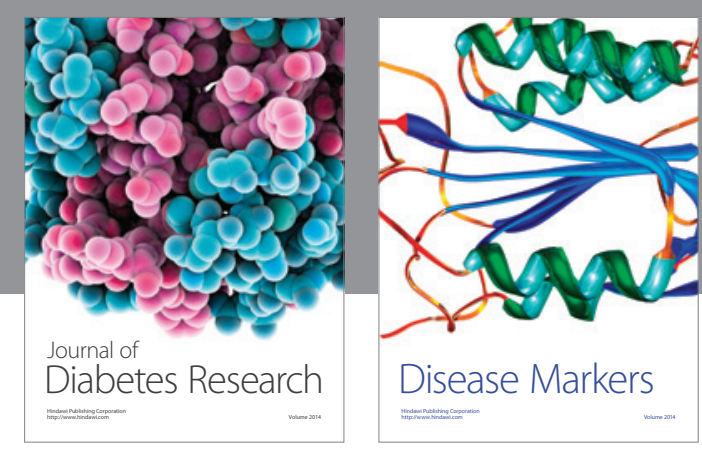

Disease Markers
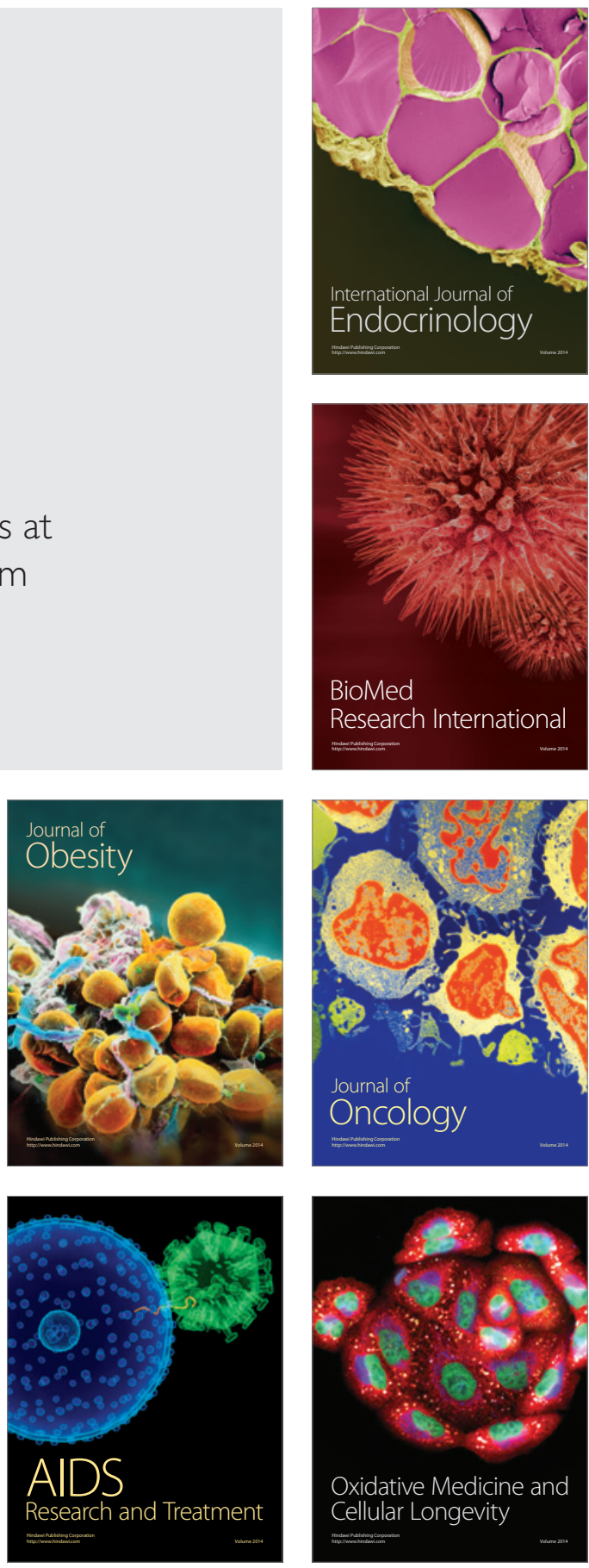